\title{
Recycle Evaluation using System Dynamics for Solid Waste Management in Malaysia
}

\author{
Faridah Zulkipli, Zulkifli Mohd Nopiah, Noor Ezlin Ahmad Basri, Cheng Jack Kie, Khairul \\ Irwan Khalid
}

\begin{abstract}
Solid waste management gained the highest significant attention globally. In Malaysia, the generation of solid waste has increased $4 \%$ approximately year by year and an average from $0.8 \mathrm{~kg} / \mathrm{cap} /$ day to $1.12 \mathrm{~kg} / \mathrm{cap} /$ day. This trend is in line with the increasing population density in Malaysia especially in urban areas. The exponential growth of economic, urbanization, demographics and changing lifestyles are the key reasons behind the increase in the generation of solid waste. The objective of this research is to develop a system dynamic model for solid waste management in peninsular Malaysia and analyze the recycle evaluation. This method has an ability to handle a complex system and dynamic behavior over time. The result show that model imitate the real system with the validation less than $+10 \%$ and $-10 \%$ of acceptance range. This model can assist the decision maker in making efficient decision. The management of solid waste department may holistically measure the alternative action in cost effective and save time. As a result, the recycle rate in Malaysia relatively low and lack of participation from public. Enforcement and engagement from all parties are needed in order to achieve a sustainable environment in future.
\end{abstract}

Keywords: Recycle, solid waste management, system dynamics.

\section{INTRODUCTION}

Solid waste management is a discipline of managing discard or unwanted thing to be disposed. This process consists of complex and dynamics behaviour and happen to be a worldwide problem, including Malaysia. Due to rapid population, changing life style, urbanization process towards sustainable development and uncontrollable increment in solid waste generation [1]-[3] made it as an fundamental and seek attention from researchers for finding a better solution for future sustainable world. The quality of life especially in urban area, where congested with citizens requires a systematic and effective of solid waste management. Therefore, the government and management of solid waste commence towards a holistic and systematic ways by introducing numerous of plans and strategies. In Malaysia, it is estimated that the amount of recyclable materials thrown to the garbage disposal site annually is 2.3 million tons with an estimated value of RM900 million. In 2013, the country's total waste generation increased to 33,000 ton per day, compared to 19,000 ton per day in 2005 [3], [4], [9]. This

Revised Version Manuscript Received on September 16, 2019.

Faridah Zulkipli, Faculty of Computer and Mathematical Sciences, Universiti Teknologi MARA, Perak Branch, Tapah Campus, 35400 Tapah Road, Perak, Malaysia.

Zulkifli Mohd Nopiah, Centre of Engineering Education Research, Universiti Kebangsaan Malaysia, Bangi, Selangor, Malaysia.

Noor Ezlin Ahmad Basri, Department of Civil and Structural Engineering, Universiti Kebangsaan Malaysia, Bangi, Selangor, Malaysia

Cheng Jack Kie, Faculty of Industrial Engineering, Universiti Malaysia Pahang, 26300 Gambang, Pahang, Malaysia.

Khairul Irwan Khalid, SWCorp Malaysia, Kementerian Kesejahteraan Bandar, Perumahan Dan Kerajaan Tempatan, Blok J, MKN Embassy Techzone, Jalan Teknolokrat 2, 63000 Cyberjaya, Selangor, Malaysia. means that the average annual solid state increase in solid waste is linearly 6.7 per cent, which is significantly higher than the average rate of increase at the international level of 3 per cent only. This also means that the rate of increase of the country's solid waste amount is twice as likely. As a developed nation, Malaysia targets 30 percent (\%) of recycling rates by 2020 [5]-[7]. The aim of this research is to develop a system dynamics model for recycling evaluation to simulate the complexity of solid waste management in Malaysia.

\section{METHODOLOGY}

\section{Location of research}

The research done with the collaboration with the local authority in solid waste management, which is Solid Waste Corporation (SWCorp) as stated in Act 673. This corporation is responsible with the strategic planning for solid waste management in Malaysia. There are some states under their supervision with mostly are located in peninsular of Malaysia. These states are tied with Act 672 as reported in strategic planning 2014-2020 [5]-[8]. Fig. 1 illustrates the states under SWCorp, which are Perlis, Kedah, Pahang, Wilayah Persekutuan Kuala Lumpur and Putrajaya, Negeri Sembilan, Melaka and Johor. All of the states are located in peninsular Malaysia. It covers an area of $130598 \mathrm{~km}^{2}$ (50424 sq mi) and had an estimated population of 1.73 million as of 2016 [9]. It is located at coordinates $4^{\circ} 00^{\prime} 0.00^{\prime \prime} \mathrm{N}, 102^{\circ} 29^{\prime} 59.99^{\prime \prime} \mathrm{E}$. The Department of Statistics Malaysia reported that the estimated population in first quarter of 2019 was 32.66 million, 32.385 million in 2018 and 32.022 million in 2017 and an increase approximately 1-2\% annually [10].

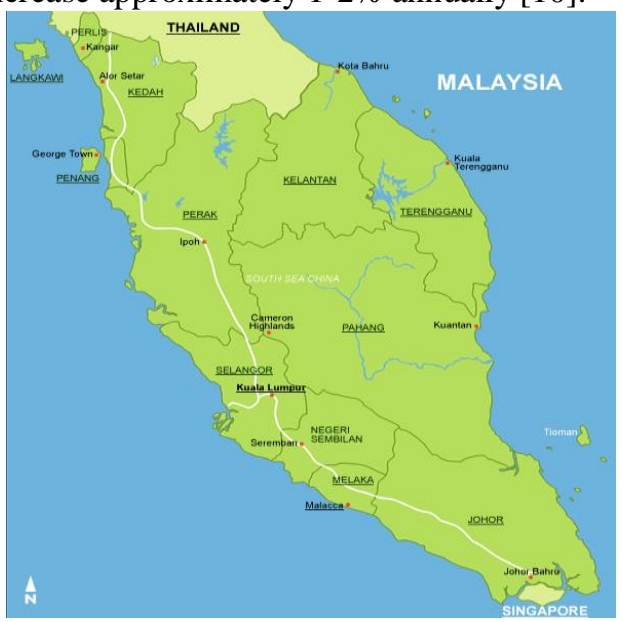

Fig. 1: States under SWCorp supervision

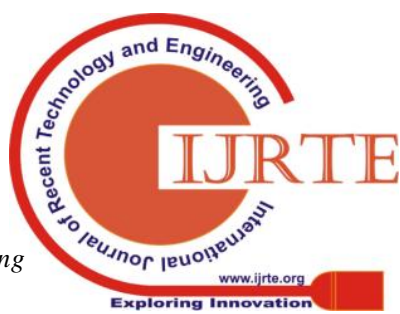




\section{System dynamics model for recycle evaluation}

System dynamics was introduced by J.W Forester in early 1960s. The method initially applied to deal with large scale system with high complexity. Due to research evolution and advancement, system dynamics method continuously applied in many areas, including engineering, finance, education and others. The method consists of five phases, which represent in Table 1 and Fig. 2. [11]-[13].

Table 2: System dynamics methodology

\begin{tabular}{|l|l|}
\hline Phase & Description \\
\hline $\begin{array}{l}\text { 1. System } \\
\text { analysis }\end{array}$ & $\begin{array}{l}\text { Identify the problem, key variables, time horizon } \\
\text { and problem boundary }\end{array}$ \\
\hline $\begin{array}{l}\text { 2. Developing } \\
\text { of dynamic } \\
\text { hypothesis }\end{array}$ & $\begin{array}{l}\text { Mapping structure, causal loop diagram, stock flow } \\
\text { diagram, model boundary chart }\end{array}$ \\
\hline $\begin{array}{l}\text { 3. Developing } \\
\text { of system } \\
\text { dynamics model }\end{array}$ & $\begin{array}{l}\text { Visualize problem into stock and flow diagram. } \\
\text { Construct a system dynamics model }\end{array}$ \\
\hline 4. Validation & Validation test for system structure and behavior \\
\hline $\begin{array}{l}\text { 5. Policy andign } \\
\text { design and } \\
\text { evaluation }\end{array}$ & Output presentation and discussion \\
\hline
\end{tabular}

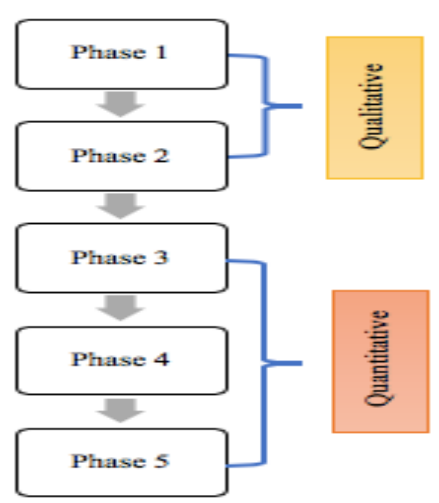

Fig. 2: System dynamics phases

\section{System dynamics model for recycle evaluation}

Due to complexity in solid waste management process, a system dynamics approach is implemented in order to develop and illustrated the recycle evaluation as in Fig. 3. The process begins with waste generation which influenced by population. Then the process waste will be sent to disposed options either landfill, compost or recycle. In Fig. 4 show the recycle rate in Malaysia from 2011 to 2015. The recycle rate had fall in 2013 and 2015 due to lack of participation and awareness from public. However, the recycle rate has increased in 2016 and recorded more than $17 \%$ after the separation at source policy had been launched in September 2015.

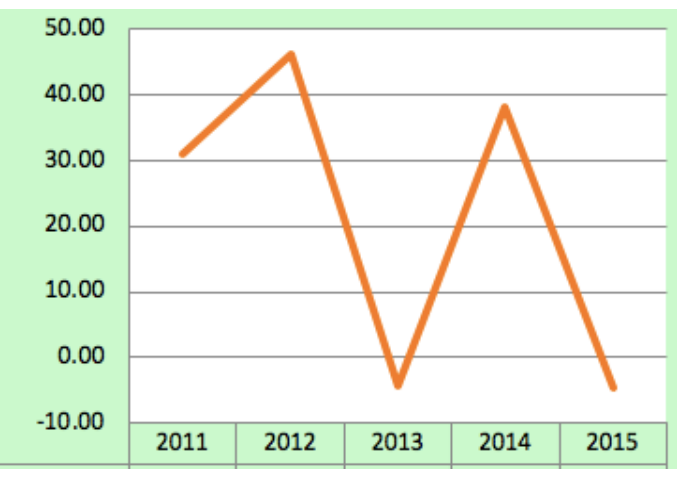

Fig. 4: Recycle rate in Malaysia from 2011 to 2015

\section{Validation test}

System dynamics is one of simulation technique which are using for imitating the real problem into simulation model. A validation test must be performed in order to validate the system dynamics model using the following equation. Assumption of the model for representing the real problem when the acceptance range is within $+10 \%$ and $-10 \%$ as in (1) [14]. Then, the result and analysis from the model are reliable and valid. The result shows in Table 2.

Validation test $=($ simulation - actual $) /$ actual $\times 100 \%$

\section{RESULTS AND DISCUSSION}

In this research, population is the main contributor towards waste generation which is based on previous studies conducted by [1], [3], [9]. The trend in Fig. 5 shows a positive increment from year 2015 to 2030. While in Fig. 6 present the waste generation in Malaysia in year 2015 until 2030. Statistics in Malaysia reported that population in 2015 was 30.7 million people and increased by $2 \%$ to $4 \%$ annually. The population increased to 32 million people in 2017 and estimated 32.6 million in 2019. The data was reported by Ministry of Housing and local Government (KPKT) in 2015. Where Malaysia generated 38563 ton/day in 2015, 40566 ton/day in 2016 and estimated to be generated approximately 50000 ton/day in 2020.There is positive relationship between population and waste generation. When the population increase, then waste generation also increase accordingly. In year 2005, the waste generated in Malaysia amounted to 19,000 tons per day with the recycling rate of 5 percent. Later, in year 2016, the quantity of recycle was 38,200 tons/day with a recycling rate of 17.5 percent. As a national plan to become a developed country and clean environment by 2020 , the recycle rate are targeted to achieve of 22 percent. Disposal of waste generation in 2015 was 38000 ton/day.

Due to successfully implemented the recycle program, the quantity of waste generation dumped in landfill area was decreased annually. It is expected declined to 10000 ton/day in 2020 as in Fig. 7.

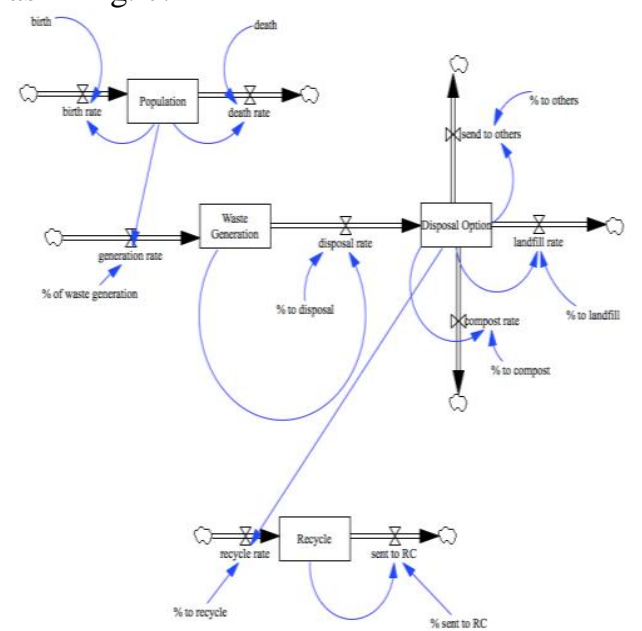

Fig. 3: Recycle model using system dynamics 


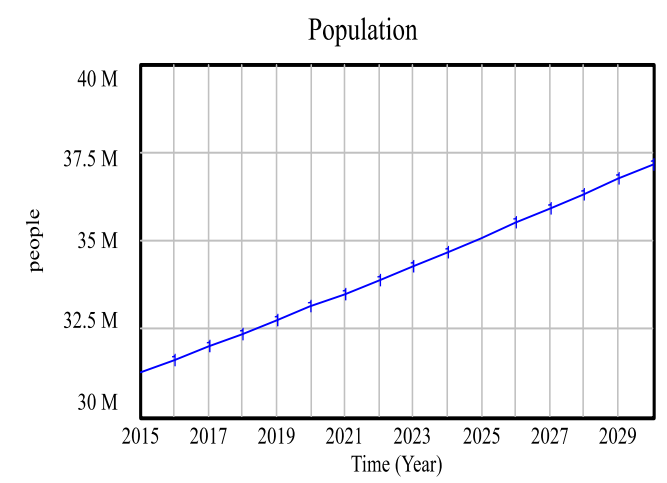

Population : Current

Fig. 5: Population in Malaysia 2015 to 2030 Waste Generation

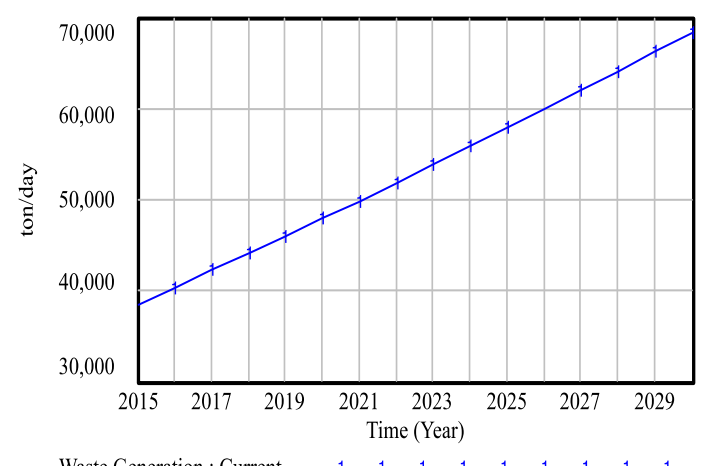

Waste Generation: Current

Table 2: Validation test

\begin{tabular}{|c|c|c|}
\hline Variables & Acceptance Range & Status \\
\hline Population & $\mathbf{1 . 1 7 \%}$ & Valid \\
\hline Waste generation & $\mathbf{- 1 . 9 1 \%}$ & Valid \\
\hline Recycle & $\mathbf{1 . 1 3 \%}$ & Valid \\
\hline \multicolumn{2}{|c}{} \\
Recycle
\end{tabular}

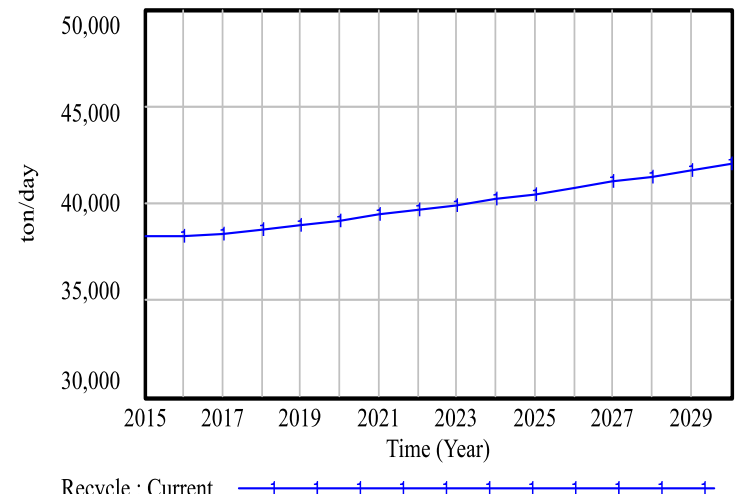

Fig. 7: Recycle evaluation 2015 to 2030

\section{CONCLUSION}

Recycle is one of the important initiatives had been implemented in every country including Malaysia for waste minimization. As a target for 2020, where Malaysia can achieve $20 \%$ of the solid waste management will be recycle before dumping in landfill area. Currently, the recycle rate in Malaysia had achieved 17\% in 2016 and looking forward to increase continuously. However, in order to achieve this mission, participation from public need to be enforced. One of the alternatives is trough mind transformation toward sustainable environment also indirectly influent the successful of becoming the cleanliness country in future. In conclusion, campaign on recycle should be highlighted and introduced in early age citizen. More collaboration and engagement between solid waste corporation and all parties are needed.

\section{ACKNOWLEDGMENT}

This research was supported by the Faculty of Computer and Mathematical Sciences (FSKM). Our sincere gratitude goes to the Universiti Teknologi MARA, Perak Branch, Tapah Campus for providing the financial research. Finally, the authors thank the Solid Waste Corporation (SWCorp) for assisting in solid waste management information.

\section{REFERENCES}

1. G. Tchobanoglous and F. Kreith. Handbook of Solid Waste Management. New York: McGraw-Hill, 2002.

2. I. Budhiarta, S. Chamhuri, and B. Hassan, "Current status of municipal solid waste generation in Malaysia," International Journal on Advanced Science, Engineering and Information Technology, 2(2), 2012, pp. 129-134.

3. F. Zulkipli, Z. Mohd Nopiah, N. E. Ahmad Basri, J. K. Cheng, and S. S. Januri, "Multilinear regression analysis on solid waste generation quantity in Malaysia towards sustainable development," International Journal of Advanced and Applied Sciences, 4(9), 2017, pp. 46-52.

4. Department of Statistics Malaysia, Taburan penduduk mengikut kawasan pihak berkuasa tempatan dan mukim e-CENCUS. Available: https://www.mycensus.gov.my/banci/www/index.php.

Kementerian Perumahan dan Kerajaan Tempatan, Annual report 2013. Available: http://www.kpkt.gov.my/resources/index/user_1/Attachm ents/hebahan_slider/slaid_dapatan_makmal.pdf.

6. Solid Waste Corporation, Annual report 2014. Available: http://www.swcorp.gov.my/docfile/laporan-tahunan/2014.pdf.

7. Jabatan Pengurusan Sisa Pepejal Negara, Ringkasan Tapak Pelupusan Sisa Pepejal di Malaysia. Available: http://jpspn.kpkt.gov.my/resources/index/user_1/Sumber_Rujukan/stati stik/ringkasan_tapak_seluruh_Malaysia.pdf.

8. Solid Waste Corporation, Solid waste and public cleansing management act. Available: http://www.swcorp.gov.my/swcorp17lama/index.php/en/kenali-kami-2/ the-act.

9. F. Zulkipli, Z. Mohd Nopiah, N. E. Ahmad Basri, and J. K. Cheng, "Stock flow diagram analysis on solid waste management in Malaysia," AIP Conference Proceedings, 1782(1), 2016, pp 1-6.

10. Department of Statistics Malaysia, Population \& demographic Available:

https://www.dosm.gov.my/v1/index.php?r=column/ctwoByCat\&parent _id=115\&menu_id=L0pheU43NWJwRWVSZklWdzQ4TlhUUT09.

11. J. D. Sterman, Business dynamics: Systems thinking and modeling for a complex world. Available: https://dspace.mit.edu/bitstream/handle/1721.1/102741/esd-wp-2003-0 1.13.pdf? sequence $=1$.

12. B. Dyson and N. B. Chang, "Forecasting municipal solid waste generation in a fast-growing urban region with system dynamics modeling," Waste Management, 25(7), 2005, pp. 669-679.

13. S. Hasimah, Z. Jafri, A. Norazura, Z. A. Norhaslinda, and H. Nurul Nazihah, Introduction to System Dynamics Modelling and Vensim Software. Kedah: Universiti Utara Malaysia, 2015.

14. M. T. Razman, A Practical Approach to Computer Simulation Modelling. Selangor: Universiti Putra Malaysia Press, 2006. 